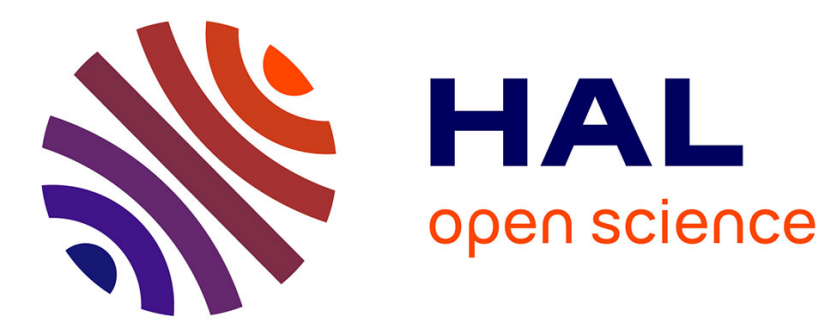

\title{
Tomatoes for processing in 90's: nutrition and crop fertilization
}

\author{
Y. Dumas
}

\section{To cite this version:}

Y. Dumas. Tomatoes for processing in 90's : nutrition and crop fertilization. 3. International Symposium, Nov 1989, Avignon, France. hal-02777124

\section{HAL Id: hal-02777124 \\ https://hal.inrae.fr/hal-02777124}

Submitted on 4 Jun 2020

HAL is a multi-disciplinary open access archive for the deposit and dissemination of scientific research documents, whether they are published or not. The documents may come from teaching and research institutions in France or abroad, or from public or private research centers.
L'archive ouverte pluridisciplinaire HAL, est destinée au dépôt et à la diffusion de documents scientifiques de niveau recherche, publiés ou non, émanant des établissements d'enseignement et de recherche français ou étrangers, des laboratoires publics ou privés. 
TOMATOES FOR PROCESSING IN 90'S : NUTRITION AND CROP FERTILIZATION

Y. Dumas

Institut National de la Recherche Agronomique

Station d'Agronomie

B.P. 91, 84140 Montfavet

Erance

\section{Abstract}

A brief review of nutrition and fertilization of processing tomato is presented. Datas are given about nutrient requirements and mineral absorption rhythms which are highest during flowering and fruit setting especially for machine harvested cultivars. Main nutrient specificities towards production quantity or quality are recalled. Fertilization must be reasoned according to orop demand and soil availability for a definite production objective which may be different from maximum yleld and have to be combined with other aims such as unwasting of resources and minimum pollution of the environment. This leads to try to improve fertilization efficiency. Fertilizer placement is a possibility which is illustrated here by research results, trickle fertigation is another way but it is not still possible to adopt it anywhere. Further progress is expected from basic research on nutrient dynamics in soil but also from modeling and simulating field crop functioning and from using genetic variability too. Anyway research must go on helping producers to fertilize in a reasoned and responsible way.

\section{Introduction}

During the last 20 and even 30 years a great number of studies were carried out about nutrition and fertilization of processing tomato. one could believe that everything is roughly well known. However plant material is always changing, production context and objectives are progressively modified (e.g. mechanical harvest), new cultural techniques appear (e.g. mulching or drip irrigation), which questions research workers and producers at any moment. So it is much important not to forget fertilization which must not become in crop management.

In this article a first point of view will deal with crop nutrition per se which concerns a large group of phenomenas from nutrient penetration Into the root to its metabolism in the plant components. Only main points will be recalled. A second point of view will concern fertilization which simply is a technical action to supply crops with na-
tural or synthetic nutrients.

\section{Mineral nutrition}

\subsection{Nutrient_requirements}

Nutrient uptake is continuous during growth and development of the tomato plant (Halbrooks et al., 1980) if no drastic limiting factor appears and it begins very early, almost as soon as emergence (Suniaga, 1990 in the present volume). For instance phosphorus deficiency 
can be already observed through a purple colour when the second true leaf appears a few days after seeding emergence (Dumas, 1988). Table 1 gives data about nutrient requirements of a tomato crop (UCB2) seeded and managed for mechanical harvest near Avignon in the S.E. of France. These data correspond to common average values. But Maestrey and al.(1987) found that the amount of each nutrient present in the total biomass of spring tomato per tonne of fruit produced ranged from 2.3 to $3.9 \mathrm{~kg} \mathrm{~N}$, from 0.28 to $0.42 \mathrm{~kg} \mathrm{P}$ and from 3.4 to $4.9 \mathrm{~kg} \mathrm{~K}$. These variations come either from differences among cultivars (Tesi et al., 1988) or from cropping conditions. It nevertheless can lead to very high uptakes of $\mathrm{N}, \mathrm{K}$ or $\mathrm{Ca}$. It is interesting to note that 60 to $70 \%$ of $N, P$ or $K$ are concentrated in fruits at harvest time. However. it is necessary to see beyond these global numbers.

\subsection{Mineral absorption rhythms}

Figure 1 shows shoot dry matter accumulation per unit area for the same crop as in table 1. It consists of a classical sigmoid curve with various rates along the cycle e.g. a low one during the pure vegetative stage, a higher one when the first trusses appear, a very high one during the overlapping time of "flowering - fruit setting early fruit swelling", and a slower one during fruit ripening. Growth relays can be observed among the plant components, as branching decreases and then stops with fruit set and expansion respectively. Identical curves exist for the main nutrients $N, P$ and $K$. Figure 2 shows phosphorus example. Of course if total $P$ uptake was $40 \mathrm{~kg} \mathrm{ha-1}$, which is low, total $\mathrm{N}$ and $K$ uptakes were 260 and $400 \mathrm{~kg} \mathrm{ha}-1$ respectively. Studies report that highest uptake rates take place between 40 and 70 days after planting (Graifenberg et al.. 1987). In our example daily uptake during flowering was $4.3,0.7$ and $8.3 \mathrm{~kg} \mathrm{ha}^{-1}$ for $\mathrm{N}, \mathrm{P}$ and $K$. It is all the more intense because mechanical harvest induces cultivars with concentrated fruit set. About $70 \%$ of the $K$ accumulated in the plant at harvest can be taken up during fruiting (Widders et al., 1982). K deficiency symptoms can be observed due to the inability of the root system of certain cultivars to absorb $K$ at a rate sufficient to meet the demand (Widders et al., 1979, Maynard et al., 1980).

\subsection{Main nutrient specificities}

2.3.1. Nitrogen undoubtly affects vegetative growth and fruit production more than any other nutrient. $N$ excess can be as unfavourable as deficiency especially in a mechanical harvest context or towards fruit quality by decreasing size, colour and solid content. It can also have indirect effects, for instance transplants bred under high $N$ levels are more sensible to metribuzin toxicity after planting (Nelson et al.. 1980). $140 \mathrm{mg} \mathrm{N} 1^{-1}$ has been considered as an optimum concentration of the solution where plants take up in sandy soils (Bar-Yosef, 1977). This must be varied according to growth stages, with $100 \mathrm{ppm}$ as a threshold value and $300 \mathrm{ppm}$ as a top one (Bar-Yosef et al., 1982). N is preferentially absorbed by tomato as nitrate and with better results. But ammonium is also absorbed. High $100 \mathrm{x}_{4}{ }^{+}$ concentration inhibits growth with toxicity symptoms, but a $\mathrm{NO}_{3}{ }^{-} / \mathrm{NH}_{4}{ }^{+}$ ratio of $75 / 25$ appears better than either $\mathbb{N}$ source alone (Wilcox et al., 1985, Castellane et al., 1987). In fact, such sand culture or nutrient solution results sometimes differ and it is difficult to transpose them to field where high $\mathrm{NH}_{4}{ }^{+}$contents are uncommon. 
2.3.2. Phosphorus is necessary to growth and development with positive effects on the number of flowers (El-Sawah, 1985), ripening earliness and concentration, and on fruit quality (coloration, vitamin $C$ content, however difficult to quantify). Total $P$ requirements are Iow but tomato crops show a high demand towards $\mathrm{P}$ availability at the beginning of its cycle owing to a very small root system, a very low $p$ mobility and sometimes limiting temperatures. Young plant $P$ deficiency are well known through small purple stiff erected leaves.

2.3.3. Potassium is considered to have a great infiuence above all on fruit quality through ripening processes. It improves coloration by increasing pigmentation. "Blotchy ripening" is associated to $K$ deficiency. Sufficient $K$ nutrition increases solid content, sugars, acids, carotene, lycopene and keeping qualities. Growing plants at $1000 \mathrm{mg} \mathrm{K} \mathrm{I}^{-1}$ allows intensive red colour (Borkowski et al., 1986).

2.3.4. Calcium is generally associated with a well known disorder called "blossom end rot" which greatly depreciates yields. In fact it may appear even with high $\mathrm{Ca}$ content in salinity or water stress conditions (Pill et al., 1980, Ehret et al., 1986). Other cation antagonism also increases it such as under high $\mathrm{K}^{+}$or $\mathrm{NH}_{4}^{+}$content in the medium (Besford et al., 1978, De Kock et al., 1979, Carpena et al., 1986, Cerne, 1990 in the pregent volume).

2.3.5. Interactions then exist between ions (antagonism or synergism), which is a great complication for agronomists. Buffering propertles of solls often will moderate nutrient relations. Moreover, various factors will affect plant response to nutrients, such as soil pH which modifies nutrient availability, temperature which limits element absorption, salinity, water supply (Kaniszewski et al., 1987), soil compaction and even genotype (Barker, 1989). Many research workers have tried to achieve a nutrition diagnosis through tissue analysis, e.g. leaves. Nutrition indexes have been made with data on the nutrient content of tomato components at various growth stages under hydroponic conditions (Carpena Artes et al., 1987) for use as reference values for adequate nutrition. It expresses what is wanted, but the question remains to know how to reach it in soil conditions, which are rather different.

\section{Fertilization}

\subsection{Objectives and_contraints}

Processing tomatoes are cultured on many soil types which of course never present a perfect nutrient status. So farmers have to supply crops with nutrients by means of soil and, there, things become complicated for we only have a global and vague knowledge of what happens in soil profiles. Particular cases really are precisely described but no general theory exists which could allow to treat of any situation.

Nevertheless, in this context, fertilization is the only technical means to try to optimise the adjustment between successive instantaneous crop demands and successive instantaneous soil availabilities for a definite quantitative and qualitative production objective. This objective is not necessarily the maximum yield. It will depend on various factors, e.g. economical considerations or farmers' own strate- 
gies such as will to reduce production costs or to give priority to other crops, medium potentialities as it is not good to fertilize for $120 \mathrm{t} \mathrm{ha}^{-1}$ if soll or climate potentlalities allow to expect only 60 .

Other constraints have to be considered such as unwasting of expensive nutrients like $\mathrm{N}$ and $\mathrm{K}$ and unrenewed ones like $\mathrm{P}$, limitation of raw material importation to reduce the balance of trade deficit, limitation of pollution risks such as nitrate leaching towards ground water rivers and lakes.

\subsection{Fert1lization reasoning}

If it is aditted that we can determine production potential for any situation, which is not evident, three main points have to be considered for fertilization reasoning.

\subsubsection{Knowledge of plant requirements and uptake capacity}

More than total plant reguirements per cultivar it is important to know their kinetics during the growth cycle. At any moment nutrient uptake (figure 3 a) is given by the relation $\theta=\Sigma_{t} d \theta / d t$. As this relation is generally unknown it is possible to approach it by dividing the growth time into periods of very different absorption rates e.g. four ones as indicated on figure 3 a and discribed in 2.2. Curve portions may be assimilated to linear segments the slopes of which $(a, b$, c, d) represent mean daily requirements. This allows to better estimate successive nutrient requirements, the total being :

$Q=a\left(t_{1}-t_{0}\right)+b\left(t_{2}-t_{1}\right)+c\left(t_{3}-t_{2}\right)+d\left(t_{4}-t_{3}\right)$.

At the same time the rooting system is expanding ( figure $3 \mathrm{~b}$ ) with an evolution of its uptake capacity owing to bigger and bigger soil volumes explored in mediums where nutrient concentrations and absorption conditions (moisture, aeration) often differ. Uptake rates will roughly depend on rooting depth distribution and density and on nutrient availability in the soil.

\subsubsection{Knowledge of soil nutrient availability}

Till now one can only make diagnoses, which remain critical, from soil analysis after chemical extractions. In fact it remains unsufficient as it gives an idea of the nutrient stock, total or "available" but not of the soil feeding capacity. It is a static but not dynamic view. Indeed for $\mathrm{NO}_{3}{ }^{-}$there is a great variability within time and space according to environmental conditions (mineralisation, reorganisation, leaching). For $P$ and $K$ it has been shown that tomato roots could have a very high extraction capacity (Maertens et al., 1988): $80 x$ of $P$ or $K$ absorbed by plants can come from the soil $P$ or $K$ part which was not given as "avatlable" by analysis. These are now unpredictable phenomena for any soil. Further basic studies are needed, and now fertilizer estimations remain rather vague or arbitrary.

\subsubsection{Fertilizer efficiency}

The proportion of $\mathrm{N}$ taken up by the crop and originating from fertilizer can reach $65 \%$ (Sweeney et al.. 1987) and often is less than 40-50\% (Miller et al., 1981) even with a very limited root systen under drip fertigation and small initial residual $N$ concentrations in the soil. For $P$ or $K$ it is no more than 15-20\%. This most often leads to supply crops with highly soluble fertilizers a short time before use by plants and to deliver them in the functioning root area at the right time. For example ammonitrate is often given as a better nitro- 
gen source than sulphur-coated urea, a slow-release source (McArdle et al., 1986, Sweeney et al., 1987). There are also divergent results about splitting or not supplies, especially for $\mathrm{N}$ or $\mathrm{K}$. It widely depends on production objectives and conditions.

\subsection{Mode of fertilization}

It is not possible for all fertilizer supply types or amounts or fertilizer sources to be reviewed here. No general "recipe" exists either. Only a few particular cases are approached. In poor soils low fertilizer efficiency leads to advice, one to supply great amounts, e.g. 10 times as much as crop demand for $p$ (Magalhaes et al..1986). Papadopoulos (1985) reported that a very high yield (177 t ha ${ }^{-1}$ ) was established with $1062 \mathrm{~kg} \mathrm{~N} \mathrm{ha}^{-1}$, i.e. twice the demand. Effectively the higher the supply is the higher the plant use is but the higher losses are through retrogradation or leaching. Instead of enriching the whole ploughed volume of soil with great amounts of fertilizer, it often can be possible to satisfy crop requirements by placing small or moderate quantities in the area where roots will grow at the critical time. Proper placement and time of application are best practices to increase efficiency (Lorenz, 1975).

\subsubsection{Fertilizer placement}

Starter fertilizing by placement of ammonium phosphate at transplanting is used largely and successfully. In the case of direct-seeding the establishment rate of the canopy is a main factor of the crop success through competition against weeds, yield elaboration homogeneity and earliness which are essential for mechanical harvest. As soon as emergence, soil $p$ availability is most important at a moment when the root system is tiny. Experiments were performed in pots in greenhouses and in fteld to study growth rate increase of young seedlings using a fine alluvial soil (clay $530 \%$ ), calcareous (total $\mathrm{CaCO}_{3}$ $250 \%(\% 0$ with $1.2 \%$ total $\mathrm{N}, 0.044 \%$ (extract. ammon. oxal.), exchange capacity $25 \mathrm{me} / 100 \mathrm{~g}, \mathrm{~K}^{+} 1.0 \mathrm{me} / 100 \mathrm{~g}$ and $\mathrm{Mg}^{++} 3.0 \mathrm{me} / 100 \mathrm{~g}$ (extract. ammon. acet.). Treatments consisted in supplying soil with vàrious amounts and forms of phosphate fertilizers either mixed with soil or placed in the seed vicinity. Temperatures were similar to those observed in fields in spring. The main results were as follows:

* From emergence to the appearance of the first trusses, growth (table 2) and development rates greatly increased with the quantity of $P$ (triple superphosphate 00-20-00) mixed on the $0-22 \mathrm{~cm}$ layer. The number of trusses varied from 1.4 for 0 to 7.4 for $288 \mathrm{~kg} \mathrm{P}$ ha-i, 35 days after emergence. But with moderate amounts of phosphate $100-20-$ $00)$. placed elther 5 to $7 \mathrm{~cm}$ below the seeds or directly on the seeds, equivalent or better results were obtained as compared to the highest enrichment by mixing (table 3 ). Field experiments showed that it was the same for yields (Dumas, 1988). If no limiting factor afterwards, even the control. without P supply, yielded about the same but 2 weeks later and non concentrated. So, towards $P$, the most important is the plant establishment phase until first trusses and it can be successfull with moderate placed $P$ quantities, i.e. half mean local producers' supplies and at least the fifth of what could be recommended with mixing $P$ to the ploughed layer. Placement on seeds can delay $e^{-}$ mergence of a few days but it is quickly compensated for by a higher growth rate. Even in a $\mathrm{P}$ rich soil, $\mathrm{P}$ placement made the first trusses appear a few days earlier (Dumas, 1988). However $p$ enrichment never 
hastened emergence.

* Emergence and early growth rate were influenced by $P$ fertilizer form. Solid ammonium phosphate (18-20-00) placed below the seeds did not modify emergence (up to $40 \mathrm{~kg} \mathrm{P} \mathrm{ha-1)} \mathrm{but} \mathrm{strongly} \mathrm{delayed} \mathrm{further}$ development rate for 65 and $87 \mathrm{~kg} \mathrm{p}$ ha-1. When placed on the seeds it delayed total emergence of 3 days for $10 \mathrm{~kg} \mathrm{P}$ ha-1 and 8 days for 20 $\mathrm{kg} \mathrm{p} \mathrm{ha} \mathrm{H}^{-1}$, but with the same, final emergence percentage as control. placing ammonium phosphate in solution on the seeds also delayed emergence but above all reduced total emergence percentage from 93x (control) to $63 \%(20 \mathrm{~kg} \mathrm{P} \mathrm{ha-1)}$ and $33 \%(40 \mathrm{~kg} \mathrm{P} \mathrm{ha-1).} \mathrm{It} \mathrm{wag} \mathrm{never}$ observed any symptom of ammonium toxicity but high salinity levels were measured, resulting from high ammonium and above all nitrate concentrations. Moreover Churata-Masca et al. (1987) observed that applying $32 \mathrm{ml} \mathrm{m}^{-1}$ of a 10-30-00 fertilizer directly to seeds in the row was phytotoxic and that best results were obtained with a $16 \mathrm{ml}$ rate. So placing ammonium phosphate must be achieved carefully.

* In our conditions enriching the $0-10 \mathrm{~cm}$ layer with $K$ (sulphate) up to $420 \mathrm{~kg} \mathrm{~K} \mathrm{ha-1}$ did not signiflcantly increase seedling growth rate, neither did placing 80 or $160 \mathrm{~kg} \mathrm{~K} \mathrm{ha-1} \mathrm{(sulphate} \mathrm{or} \mathrm{chlorid)} \mathrm{in}$ the seed vicinity. However placement on the seeds tended to delay $e^{-}$ mergence of a few days, because of soil salinity increase. Soil Kavailability was sufficient for stand establishment. In fact satisfying results were obtained in field without $K$ supply (Dumas, 1990 in the present volume).

\subsubsection{Trickle fertigation}

Point source fertigation is of high interest, especially in arid zones and it is more often studied on sandy solls. It allows to supply daily or almost nutrient amounts according to crop requirements during the successive growth phases (\$3.2.1.). For rooting volume theorically is small and use of soil storage nutrients can be weak. It is suitable for maximising yields. The scheduling of $N$ and $K$ applied through drip irrigation systems is required to obtain high fertilizer use efficiency. However it depends on season type and location (Locascio et al., 1989). So drip irrigation use remains difficult for farmers es-. pecially because of leaching or salt accumulation risks (Bar-Yosef, 1977). It is far from being generalized except in Israel, and only beginning in France for example.

\subsubsection{Organic fertilization}

There are not many studies about this topic and organic matter does not seem to be much used as fertilizer. In the S.E. of France, organic manuring has disappeared with cattle breeding forsaking during the last 25 years. A priori tomato can grow without organic matter as it grows well in sand culture with nutritive solution. Big organic matter supplies are undoubtly interesting through their complex effects on soil properties, such as improving the storage capacity of available water or cations, stimulating or regulating soil micro- and macro-organisms, as it has been shown that $4 \mathrm{t}$ ha-1 of poultry manure lessened root-knot nematode damage (Chindo et al., 1986), or reducing soll compaction risks. Organic matter is a buffering source of nutrients, but with a release into the soil solution generally badly known. Its effect is certainly important in very poor soils, but it is now expensive and its placement may be interesting. 


\subsection{Fertilization is not to be considered separately}

Fertilization must be related to the whole crop management. It is an evidence that its practice type and efficiency are most dependent on irrigation mode, possibly interacting with other techniques, such as polyethylene mulch limiting $N$ losses (Sweeney et al., 1987). But it also depends on soil structure and rooting conditions. Very high rates of nutrient uptake are possible only where soil tilling practices are good, to permit maximum development of a healthy root system (except under strict trickle fertigation). For $p$ uptake has been found to be proportional to root surface area (Fontes et al., 1984) and $K$ is above all absorbed by young parts of growing roots (Bosc et al., 1981). So it is necessary to obtain and preserve a soil structure favourable to a deep dense and regular rooting. High fertilization can hardly be efficient in a plot characterised by soil compaction and deficient rooting. However, fertilization has also to be reasoned for sultable decisions in such unfavourable situations die to bad soil preparation or water excess ....

\section{Future prospects}

Sowe points which could be developped are :

* Elaboration of more and more complex models coupled with use of simulation in order to better represent reality. Such models could first concern the medium evolution and could give a description of the plot conditions (bio-physico-chemical characteristics of soil profile) before plant establishment, according to main stable ground characteristics, plot history, former crop effects including harvest, technical operations and climate effects since former crop harvest. Then they could concern the crop evolution itself through the soil profile characteristics (effects of techniques, climate and vegetation) and through the stand characteristics (shoots and roots). There are already numerous submodels dealing with definite factors and some models able to integrate them (wilson et al., 1987, Bussieres, 1990 in the present volume) but their application field is still too limited for fertilization reasoning.

* Use of genetic variability : progress is possible by modifying genetic characteristics of tomato. Genetic differences in $\mathbb{N}$ uptake exist between lines and depend on the size and activity of roots. A challenge in plant breeding is to incorporate favourable characters to include efficiency in $\mathbb{N}$ use into superior cultivars (Barker, 1989). Hochmuth et al. (1985) have studied a tomato strain referred to as "cotonny root" distinguished by exceptionally high numbers of root hairs and extremely efficient in $P$ uptake. So cultivars tolerant to $P$ defictency can be bred for use under conditiong of limited $P$ availability. Improvements are to be expected through genetic manipulation of the root system, since $30 \%$ of the genome conditioning root characteristics remains unknown (Zobel, 1986).

* Improvement of nutrient intercepting capacity of roots by inoculation of mycorrhizal fungi (Hadas et al.. 1987, Mohandas, 1987). Mycorrhization increases root contact area with soil and solution and can improve $P$ absorption capacity especially in soils poor in $P$. 


\section{Conclusion}

Fertilization does not appear to be an ordinary action. In the 90 's, for processing tomato as for other crops, it must be a reasoned one and an accountable one in relation to three main points :

* With regard to the crop itself and to the objectives which can be expected and not only according to a general-purpose maximum or to the hope of a record yleld. There is place for a somewhat less intensive cropping type using not so much inputs with a better efficiency.

* With regard to the environment that men have to protect against damage risks, such as nitrate pollution, or resource wasting risks.

* With regard to Society which have to be provided with products of high nutritive quality and health respectful.

Producers are no longer allowed to supply crops with fertilizers more or less by guess and agronomists are no longer allowed to reconmend only a maximal fertilization to them like "he who can do more can do less". Better producing must progressively take precedence over ever more producing. It is not easy now because of still poor knowledge. It is necessary to achieve a better fertilization forecast by the building of predictive models which account for field crop functioning.

Moreover research workers have to give to producers diagnosis and decision indicatiors which should be based on simple observations of crop or medium, e.g. about parasitism, nutrition state, precise state of yield elaboration.

Indeed research must keep 10-15 years of advance but it also must accompany and help the producer in his present decisions, even for crop management in non optimum conditions.

\section{References}

Barker, A.V., 1989. Genotypic responses of vegetable crops to nitrogen nutrition. Hortscience 24(4):584-591.

Bar-Yosef, B., 1977. Trickle irrigation and fertilization of tomatoes in sand dunes : water, $\mathrm{N}$, and $\mathrm{P}$ distributions in the soll and uptake by plants. Agron.J. $69(3): 486-491$.

Bar-Yosef, B., and Sagiv, B., 1982. Response of tomatoes to $N$ and water applied via a trickle irrigation system. I. Nitrogen. Agron.J. $74(4): 633-637$.

Besford, R.T., 1978. Effect of potassium nutrition of three tomato va191 .

Blatt, C.R., and McRae, K.B., 1986. Effect of irrigation and nitrogen, phosphorus and potassium rate and placement on tomato fruit yield and size. Can.J.Soil Sci. 66(4):653-660.

Borkowski, J., and Szwonek, E., 1986. Effect of potassium and magnesium on the quality of tomato fruits. Acta Hort. 191:133-139.

Bosc, M., and Maertens, C., 1981. Role de 1 'accroisgement du systeme racinalre dans l'absorption de divers etats du potassium du sol. Agrochimica 25(1):1-8.

Carpena, O.. Cadahia, C., Pefalosa, J., and Sarro, M.J., 1986. Study of $\mathrm{Ca} / \mathrm{K}$ interaction in Lycopersicon esculentum Mill. incidence in

"blossom-end rot". Acta Hort. 191:141-148. 
Carpena Artes, O., Masaguer Rodriguez, A., and Sarro Casillas, M.J., 1987. Evolución de los contenidos minerales de rals, tallo y hora de plantas de tomate como indices de nutrición. An.Edaf.Agrob. 46 $(1 / 2): 117-127$.

Castellane, P.D., Monnerat, P.H., and Rena,. A.B., 1987. Desenvolvimento inicial e composiçao mineralde tomateiros cultivados sob differentes relaçoes $\mathrm{NH}_{4}^{+}: \mathrm{NO}_{3}^{-}$. Hort.Bras. 5(1):25-29.

Churata-Masca, M.G.C., Fabiani, M.A., and Castellane, P.D., 1982. Aplicaçao de fertilizante liquido 10-30-00 na semeadura direta do tomateiro "Petomech". Hort.Bras. 5(2):37-38.

Chindo, P.S., and Khan, F.A., 1986. Effect of soil organic amendment with poultry manure on the damage caused by the root-knot nematode Meloldogyne incognita on tomato. Int. Nem. Netw. Newsl. $3(4): 30-33$.

De Kock, P.C., Hall, A., Inkson, R.H.F., and Robertson, R.A., 1979. Blossom-end rot in tomatoes. J.Sci.Food Agric. 30(5):508-514.

Dumas, Y., 1988. Influence of phosphorus fertilization and availability on growing and production of sown tomatoes. Acta Hort. 220: 245-252.

Ehret, D.L., and Ho, L.C., 1986. Translocation of calcium in relation to tomato fruit growth. Ann.Bot. 58(5):679-688.

El-Sawah, M.H., 1985. Influence of soil types, presowing treatments, available amounts of soil nutrients and their combinations on tomatoes. III. Effects on seedling growth and flowering. Act.Agr.Acad. Scient. Hung. $34(1 / 2): 94-104$.

Fontes, P.C.R., and Milcox, G.E., 1984. Growth and phosphorus uptake by tomato cultivars as influenced by phosphorus concentrations in soil and nutrient solution. J.Amer.Soc.Hort.Sci. 109(5):633-636.

Graifenberg, A., Giustiniani, L., and Temperini, 0., 1987. Crescita e asportazione degli elementi nutritivi nel pomodoro da industria. Colt.Prot. 16(3):51-55.

Hadas, R., and Okon, Y., 1987. Effect of Azospirillum brasilense inoculation on root morphology and respiration in tomato seedlings. Biol.Fert.Soils 5(3):241-247.

Halbrooks M.C., and Wilcox, G.E.,1980. Tomato plant development and elemental accumulation. J.Amer.Soc.Hort.Sci. 105(6):826-828.

Hochmuth, G.J., Gabelman, H.H., and Gerloff, G.C., 1985. A gene affecting tomato root morphology. Hortscience 20(6):1099-1101.

Kaniszewski, S., Elkner, K., and Rumpel, J. 1987. Effect of nitrogen fertilization on yield, nitrogen status in plants and quality of fruits of direct seeded tomatoes. Acta Hort. 200:195-202.

Locascio, S.J., Olson, S.M., and Rhoads, F.M., 1989. Water quantity and time of $\mathrm{N}$ and $\mathrm{K}$ application for trickle-irrigated tomatoes. J.Amer.Soc. Hort.Sci. 114(2):265-268.

Lorenz, 0.A., 1975. How efficient is your fertilizer program? Amer.Veget.Grow. $23(2): 3 \mathrm{pp}$.

Maertens, C., and Bosc, M., 1988. Détermination des possibilités d'extraction du potassium et du phosphore du sol par les racines de tomates. In: Phosphore et potassium dans les relations sol-plante : conséquences sur la fertilisation. INRA, Paris : 225-238.

Maestrey, A., Cardoza, H., Chailloux, M., and Alarcon, W., 1987. Extracción de nutrientes por el tomate en primavera. II. Consumo de nitrógeno, fosforo y potasio durante el ciclo del cultivo. Cienc. Técn.Agric.Suel.Agroq. 10(2):17-23. 
Magalhaes, J.R., Rodrigues, F.C., Rossi, P.E.F., Wilcox, G.E., and Silva, E.L.I.M., 1986. Development of phosphorus fertilizer recommendations for tomato on an oxisol. J.PI.Nutr. 9(9):1171-1184.

Maynard, D.N., Lorenz, D.A., and Magnifico, V. 1980. Growth and potassium partitioning in tomato. J.Amer.Soc.Hort. Sci. 105(1):79-82.

McArdle, R.N., and McClurg, C.A., 1986. Effects of sulfur-coated urea fertilizer regimes on production of processing tomatoes on a sandy loam. Fert.Res. 8(3):259-262.

Miller, R.J.; Rolston, D.E., Rauschkolb, R.S., and Holfe, D.W., 1981. Labeled nitrogen uptake by drip-irrtgated tomatoes. Agron.J. 73: 265-270.

Mohandas, S., 1987. Field response of tomato (Lycopersicon esculentum Mill "Pusa Ruby") to inoculation with a VA mycorrhizal fungus Glomus fasciculatum and with Azotobacter vinelandil. Plant and soil 98 (2) : 295-297.

Nelson, E.H., and Ashley, R.A., 1980. Effect of nitrogen levels on metribuzin tolerance in tomatoes. Research Report, Storrs Agricultural Experiment Station, Connecticut University $\mathrm{N}_{0} 65,17 \mathrm{pp}$.

Papadopoulos, I. 1985. Constant feeding of field-grown tomatoes irrigated with sulfate water. Plant and Soil $88(2): 231-236$.

Pill, W.G., and Lambeth, V.N., 1980. Effects of soil water regime and nitrogen form on blossom-end rot, yield, water relations, and elemental composition of tomato. J.Amer.Soc.Hort.Sci. 105(5):730-734.

Sweeney, D.W., Graetz, D.A., Bottcher, A.B., Locascio, S.J. and Campbell, K.L., 1987. Tomato yield and nitrogen recovery as influenced by irrigation method, nitrogen source, and mulch. Hortscience 22 (1): $27-29$.

Tesi, R., and Giustiniani, L., 1988. Growth and nutrient uptake of two tomato cultivars for mechanical harvesting. Acta Hort. 220:259-265.

Widders, I.E., and Lorenz, O.A., 1979. Tomato root development as related to potassium nutrition. J.Amer.Soc.Hort.Sci. 104(2):216-220.

Widders, I.E., and Lorenz, 0.A., 1982. Potassium nutrition during tomato plant development. J.Amer.Soc.Hort.Sci. 107(6):960-964.

Wilcox, G.E., Magalhaes, J.R., and Silva, F.L.I.M., 1985. Ammonium and nitrate concentrations as factors in tomato growth and nutrient uptake. J.P1. Nutr. 8(11):989-998.

Wilson, L.T., Tennyson, R., Gutierrez, A.P., and Zalom, F.G., 1987. A physiological based model for processing tomatoes : crop and pest management. Acta Hort. 200:125-132.

Zobel, R.W., 1986. Rhizogenetics (root genetics) of vegetable crops. Hortscience 21(4):956-959. 
Table 1 - Total nutrient requirements (vegetation and fruit) of a direct-seeded tomato crop (UC82) which produced about $90 \mathrm{t}$ $\mathrm{ha}^{-1}$ in the S.E. of France ( $\mathrm{kg}$ nutrient per tonne of fruit).

\begin{tabular}{llllllll} 
Nutrient & $\mathrm{N}$ & $\mathrm{P}_{2} \mathrm{O}_{5}$ & $\mathrm{P}$ & $\mathrm{K}_{2} \mathrm{O}$ & $\mathrm{K}$ & $\mathrm{Ca}$ & $\mathrm{Mg}$ \\
Requirement & 3.0 & 0.9 & 0.4 & 5.0 & 4.2 & 2.5 & 0.45 \\
\hline
\end{tabular}

Table 2 - Influence of the applied quantity of phosphorus (granulated triple superphosphate) mixed on the $0-22 \mathrm{~cm}$ soil layer on shoot dry matter per plant, 35 days after emergence, in pots in greenhouse.

\begin{tabular}{|c|c|c|c|c|c|c|c|c|}
\hline \multirow[b]{2}{*}{ Treatment } & \multicolumn{8}{|c|}{$P$ mixed on $0-22 \mathrm{~cm}$ (equivalent $\mathrm{kg} \mathrm{ha}^{-1}$ ) } \\
\hline & 0 & 22 & 44 & 66 & 96 & 144 & 192 & 288 \\
\hline $\begin{array}{l}\text { shoot dry } \\
\text { datter }(g)\end{array}$ & 0.27 & $\begin{array}{l}0.62 \\
e\end{array}$ & $\begin{array}{l}0.82 \\
d e\end{array}$ & $\begin{array}{l}0.86 \\
\text { d e }\end{array}$ & $\begin{array}{l}1.09 \\
d\end{array}$ & $\begin{array}{l}1.62 \\
\mathrm{c}\end{array}$ & $\begin{array}{l}2.14 \\
b\end{array}$ & $\begin{array}{l}2.53 \\
a\end{array}$ \\
\hline
\end{tabular}

Results accompanied by the same letter are not significantly different according to Newman-Keuls test $(p=0.05)$.

Table 3 - Influence of the placement of moderate amounts of phosphorus (granulated triple superphosphate) on shoot dry matter and number of trusses per plant, 35 days after emergence in pots in greenhouge.

\begin{tabular}{|c|c|c|c|c|c|c|c|}
\hline \multirow[b]{2}{*}{ Treatment } & \multirow{2}{*}{$\begin{array}{l}\mathrm{p}\left(\mathrm{eq}, \mathrm{kg} \mathrm{ha} \mathrm{g}^{-1} \text { ) }\right. \\
\text { mixed on } 0-22 \mathrm{~cm} \\
288\end{array}$} & \multicolumn{3}{|c|}{$\begin{array}{l}\mathrm{P} \text { (equiv. } \mathrm{kg} \mathrm{ha}{ }^{-1} \text { ) } \\
\text { placed under geeds }\end{array}$} & \multicolumn{3}{|c|}{$\begin{array}{l}\mathrm{P} \text { (equiv. } \mathrm{kg} \mathrm{ha}-1 \text { ) } \\
\text { placed on seeds }\end{array}$} \\
\hline & & 22 & 44 & 66 & 22 & 44 & 66 \\
\hline $\begin{array}{l}\text { Shoot dry } \\
\text { matter }(g)\end{array}$ & $\begin{array}{l}2.53 \\
b\end{array}$ & $\begin{array}{l}2.28 \\
b\end{array}$ & $\begin{array}{l}3.14 \\
a\end{array}$ & $\begin{array}{l}3.12 \\
\mathrm{a}\end{array}$ & $\begin{array}{l}2.65 \\
a b\end{array}$ & $\begin{array}{l}3.1 \\
a\end{array}$ & $\begin{array}{l}3 . \\
a\end{array}$ \\
\hline $\begin{array}{l}\text { No of } \\
\text { trusses }\end{array}$ & $\begin{array}{l}7.4 \\
a b\end{array}$ & $\begin{array}{l}5.8 \\
b\end{array}$ & $\begin{array}{l}9.1 \\
a\end{array}$ & $\begin{array}{l}7.7 \\
a \quad b\end{array}$ & $\begin{array}{l}7.3 \\
a b\end{array}$ & $\begin{array}{l}6.9 \\
\text { a b }\end{array}$ & $\begin{array}{l}8.0 \\
a \text { b }\end{array}$ \\
\hline
\end{tabular}

Results accompanied by the same letter are not significantly different according to Newman-Keuls test $(P=0.05)$. 


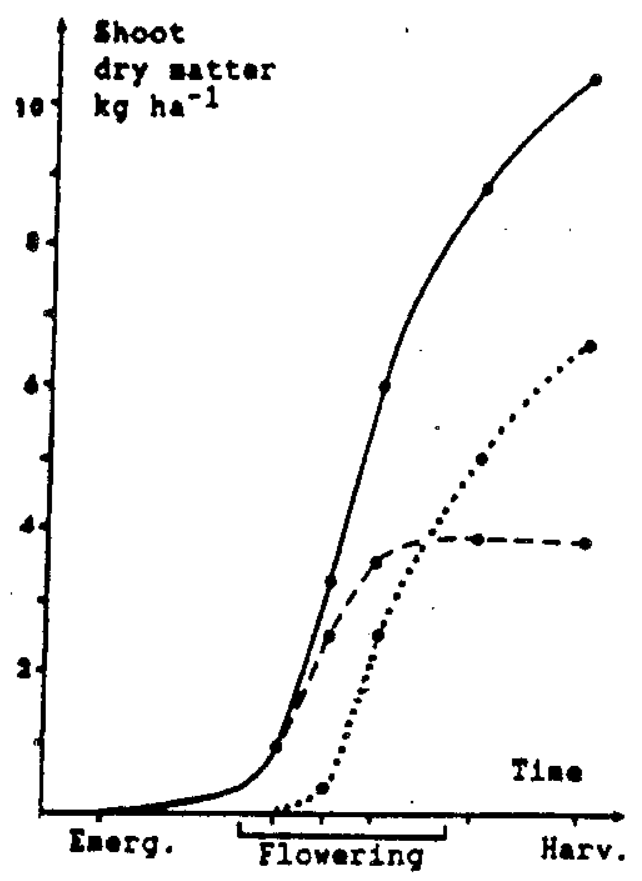

F1gure 1 - Shoot dry natter production during growth cycle.
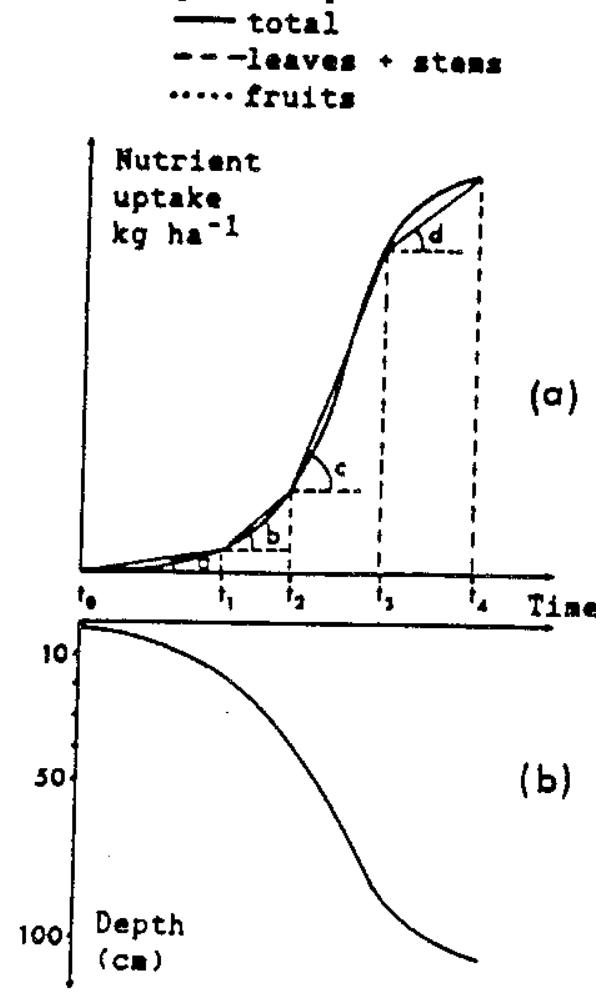

(b)

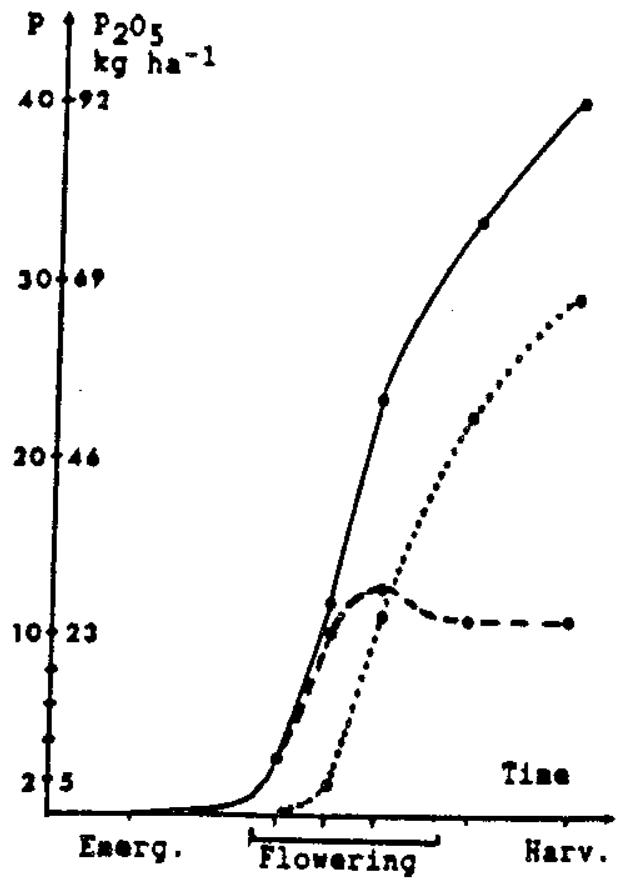

Figure 2 - Phosphorus uptake during tonato growth cycle. total

--oleaves + eteus ....etruita

Figure 3 - Nutrient uptake ratas and root syatan expansion during tonato growth cycle. 